Original Research

\title{
The Correlation Between Motivation and Health Locus of Control with Dietary Adherence of Diabetes
}

\author{
Kusnanto Kusnanto ${ }^{1}$, Retno Dwi Susanti' ${ }^{1}$ Lailatun Ni'mah' ${ }^{1}$ and Hakim Zulkarnain ${ }^{2}$ \\ 1 Fakultas Keperawatan Universitas Airlangga, Indonesia \\ 2 EMMEC, School of Health, University of Algarve, Portugal
}

\begin{abstract}
Introduction: Controlling blood sugar can be done by dietary adherence of DM. To control glycemic, it is necessary to have motivation and health locus of control to face boredom in dietary adherence of DM. The aim was to analyse the correlation between motivation and health locus of control with dietary adherence of DM.
\end{abstract}

Methods: Cross-sectional design was conducted and involved 106 respondents from five public health centers in Surabaya selected by random sampling. Data were collected by questionnaire Treatment Self-Regulation Questionnaire (TSRQ), Multidimensional Health Locus of Control Scales" (MHLC), and Diet Adherence. The analysis data was using statistical Spearman rho $(\alpha \leq 0.05)$.

Results: There was no correlation between motivation and dietary adherence $(\mathrm{p}=0.178)$, and there was a correlation between health locus of control with dietary adherence $(\mathrm{p}=0.002)$.

Conclusion: According to analysis, it can be concluded that motivation is influenced by many things to the role the forming of patient behavior in dietary adherence of DM while health locus of control has an influence to dietary adherence of DM. Because of that, it is necessary to increase the factor that influences the behavior of DM control. One of it is health locus of control. So that the glycemic control with dietary adherence of DM can increase and be better.

\section{ARTICLE HISTORY}

Received: Sept 14, 2018

Accepted: December 14, 2018

\section{KEYWORDS}

dietary adherence; glycemic control; health locus of control; motivation; diabetes mellitus

\section{CONTACT}

Kusnanto Kusnanto $\triangle$ kusnanto@fkp.unair.ac.id $\doteq$ Fakultas Keperawatan Universitas Airlangga, Indonesia

Cite this as: Kusnanto, K., Susanti, R.D., Ni'mah, L., \& Zulkarnain, H. (2018). The Correlation Between Motivation and Health Locus of Control with Dietary Adherence of Diabetes Mellitus. Jurnal Ners, 13(2), 171-177. doi:http://dx.doi.org/10.20473/jn.v13i2.9700

\section{INTRODUCTION}

Diabetes mellitus (DM) is a chronic metabolic disorder due to the pancreas being unable to produce enough insulin or the body cannot use insulin that is produced effectively (Kementrian Kesehatan RI, 2014). International Diabetes Federation (2017) reported that the number of DM patients in the world in 2017 reached 425 million adults with age ranged between 20-79 years. More than $79 \%$ of patients live in developing countries, and it is estimated that by 2045 the number of people with DM will increase to 629 million people. The International Diabetes Federation also reports that Indonesia is among the top 10 countries with the highest number of DM with 10.3 million people and is estimated to increase to 16.7 million in 2045 (International Diabetes Federation, 2017).

WHO predicts the increase in the number of people with diabetes in Indonesia from 8.4 million in
2000 to around 21.3 million in 2030. The report shows an increase in the number of people with diabetes by 2-3 times by 2035 (Perkeni, 2015). Basic health research in 2013 showed that the prevalence of DM in East Java was 2.1\%, the prevalence experienced an increase in the prevalence of 1.1 when compared with the results of Riskesdas in 2007. The number of DM patients increased from 2007 to 2013 amounting to 330,512 patients (Kementrian Kesehatan RI, 2014). The prevalence of diabetics in East Java province ranks ninth with a prevalence of 6.8, while Surabaya prevalence is higher than in East Java, which is 7 (Kominfo, 2015). The 2016 Health Office annual report shows 32,381 DM patients went to the health center in Surabaya (Dinkes Jatim, 2016). Preliminary study conducted by researchers on 24 to 25 April 2018 there were 2,195 DM patients from January to March 2018 and spread in five health centers with the highest number of DM in Surabaya. 
DM can be controlled well by diet, exercise, and antidiabetic drug therapy. Setting diet and physical activity is the main thing in DM management (Perkeni, 2015). Diet and weight control are the basis of diabetes mellitus management. If dietary adherence is carried out by DM patients, primary and secondary treatment can be performed optimally. The World Health Organization (2003) explained that the average patient's adherence to long-term therapy for chronic diseases in developed countries was only $50 \%$ while in developing countries the number was even lower. Patient adherence is needed to achieve therapeutic success, especially in diabetes mellitus. If a DM patient does not have self-awareness to be obedient, it can cause a failure in treatment which results in a decrease in health. Non-adherence in maintaining health affects the complications of DM and can lead to death (Saifunurmazah, 2013). International Diabetes Federation (2017) estimates that nearly 200 million people with diabetes are undiagnosed and more at risk of developing complications, which include kidney failure, blindness, amputation, heart disease, and stroke. Diabetic complications can be prevented by optimal glycemic control, however, in Indonesia, the target of achieving glycemic control is still not satisfactorily achieved, most of which is still above the desired target of 7\% (Perkeni, 2015). The research conducted by Tera (2011) said that the determinants of diet disobedience of patients with type 2 diabetes from 13 respondents showed that there were no respondents who made a meal arrangement according to the amount of energy, type of food and recommended food schedule.

Controlling sugar levels by regulating diet in DM patients is not easy, boredom will certainly arise because the menu consumed is limited. Motivation can control patients in regulating blood glucose levels. Motivation is very important because it can make someone do something to achieve the desired goal (Indarwati et al., 2012). Research conducted by Indarwati et al. (2012) stated that there was a significant relationship between motivation on the DM diet and respondents who were highly motivated to have 7 times the opportunity to comply with the diet compared to respondents with low motivation. In addition to motivational factors, health locus of control (HLOC) also affects DM diet adherence. Health locus of control (HLOC) is a set of beliefs about a person who has an influence on health and is one of the factors that influence DM diet adherence (Bonichini, Axia and Bornstein, 2009). Health locus of control will affect the extent to which individuals will adhere to the diet being carried out (Indriyati, D. S. \& Widyarini, 2012). HLOC is divided into two, namely internal and external HLOC. Individuals with internal HLOC will tend to work hard to take action to recover, always try to find problem solving, always think as effectively as possible and always have the perception that hard work must be done if they want to recover. Meanwhile individuals with external health locus of control will be more passive, less have initiative, less seek information to solve problems and less like to try because individuals believe that the outside factors control themselves (Adnyani, Widyanthari, and Kadek Saputra, 2015). Each individual has a different locus of control because individuals have different judgments and experiences that will affect their behavior.

The purpose of the study was to identify the relationship between motivation and health locus of control with dietary adherence in patients with DM.

\section{MATERIALS AND METHODS}

The research design used was descriptive correlation research with a cross-sectional approach. The data collection process was carried out on 3-14 July 2018 in five public health centers in Surabaya. The variables of this study were motivation, health locus of control, and adherence with DM diets. The population used in this study were 2,195 DM patients from January to March 2018 and spread in five health centers with the highest number of DM in Surabaya. Samples were obtained using proportional random sampling with inclusion criteria: 1) DM patients aged 35-55 years old; 2) Patients with DM who did not use insulin injection 3) Patients diagnosed with DM for more than one year. The number of samples in this study was 106 respondents.

Data collection techniques were carried out using a questionnaire Treatment Self-Regulation Questionnaire (TSRQ) by (Butler, 2002). TSRQ is used to measure patient motivation based on intrinsic motivation (autonomy) and extrinsic motivation (control). The questionnaire used was a modified questionnaire from Zycinska et al. (2012) which consisted of 11 items used to measure motivation in the DM diet. Modifications made were only using statement items related to DM diet motivation, and changing seven-point Likert scale into four Likert scales. The assessment uses a Likert scale: 1) strongly disagree, 2) disagree, 3) agree, 4) strongly agree. Total motivation score: 11-44. Grouped into 2, namely: good ( $\geq 80 \%$ total value or $35.2)$ and not good ( $<80 \%$ total value or $<35.2)$.

The Multidimensional Health Locus of Control Scales (MHLC) by Walltson to measure health locus of control. This scale on this questionnaire is designed for health-related conditions and has 18 items with 3 independent subscales, namely Internal health locus of control, Powerful others health locus of control, Chance health locus of control. There are alternative answers, namely 6) strongly disagree, 5) quite agree, 4) slightly agree, 3) slightly disagree, 2) enough disagree, 1) strongly disagree. Grouped into 2, namely: Height: $\mathrm{X} \geq$ Mean, Low: $\mathrm{X}<$ Mean

Dependent variable data were obtained from filling out the questionnaire about dietary compliance made by Haryono (2009) and modified by Permatasari (2014). The purpose of the questionnaire modification is to clarify the question 
so that there is no mistake in understanding the questions in the questionnaire. The dietary compliance questionnaire contained: adherence to the meal schedule (4 items), adherence to choosing the type of food (8 items), compliance in the number of foods (1 item), adherence to maintaining weight (1 item) and adherence to medication (4 items). The diet compliance questionnaire consisted of 18 questions with alternative answers namely 4) always, 3) often, 2) rarely and 1) never. Questions consist of positive and negative questions. Positive number questions $(1,2,8,9,10,16,17$ and 18) negative number questions $(3,4,5,6,7,12,13,14$, and 15) with adherence scoring namely the range of scores 18-72 with the following categories: Poor (18$<36$ ), Enough (36- <54), Good (54-72).

Data analysis using This study was analyzed in univariate and multivariate analysis tests using Spearman rho which is $\alpha=0.05$. This study has passed the ethical review of the Health Research Ethics Commission of the Faculty of Nursing Universitas Airlangga and received approval of the research protocol with number 963-KEPK.

\section{RESULTS}

The results of this study will be presented in table form. The results of this study will present data on the characteristics of respondents, motivation, health locus of control, dietary adherence of DM patients, the relationship of motivation with dietary adherence and health locus of control relationship with DM diet adherence.

Table 1 shows the characteristics of the research subjects, namely the respondents included in the highest age group were the elderly group (46-65 years) wherein this study there were 97 people (91.5\%). This study dominated female respondents, namely some $88(83 \%)$ respondents. The highest respondent status is with a married status of 79 (74.5\%) respondents. The highest distribution of respondents seen from the length of diabetes mellitus is having a history of diabetes mellitus for 15.9 years, namely 81 (76.4\%) respondents. The majority of respondents' education is basic education, namely 63 (59.4\%) respondents. As well as judging from the consumption of drugs, the majority of respondents took the drug Glibenclamide and Metformin as many as 39 (36.8\%) respondents.

Table 2 shows the motivational variables of 106 respondents, the percentage of motivations of the most respondents is poor extrinsic motivation as many as 99 (93.4\%) respondents. Extrinsic motivation is good for 7 (6.6\%) respondents. Intrinsic motivation is not good for 41 (38.7\%) respondents and good intrinsic motivation 65 $(61.3 \%)$. These data indicate that respondents from this study are more dominant, namely, motivation originating from themselves (intrinsic).

Table 1. Distribution of Demographic Characteristics of Respondents ( $\mathrm{n}=106$ )

\begin{tabular}{|c|c|c|}
\hline Respondent Characteristics & $f(x)$ & $\%$ \\
\hline \multicolumn{3}{|l|}{ Age } \\
\hline $36-45$ years & 9 & 8.5 \\
\hline $46-55$ years & 97 & 91.5 \\
\hline \multicolumn{3}{|l|}{ Gender } \\
\hline Male & 18 & 17 \\
\hline Female & 88 & 83 \\
\hline \multicolumn{3}{|l|}{ Marital Status } \\
\hline Married & 79 & 74.5 \\
\hline Widower & 27 & 25.5 \\
\hline \multicolumn{3}{|l|}{ Diabetes Suffering Period } \\
\hline $1-5.9$ years & 81 & 76.4 \\
\hline $6-10$ years & 18 & 17 \\
\hline$>10$ years & 7 & 6.6 \\
\hline \multicolumn{3}{|l|}{ Education } \\
\hline Un formally educated & 13 & 12.3 \\
\hline Elementary School & 63 & 59.4 \\
\hline Junior to Senior High School & 28 & 26.4 \\
\hline Higher Education & 2 & 1.9 \\
\hline \multicolumn{3}{|l|}{ Medicine Consumed } \\
\hline Do Not Use & 5 & 4.7 \\
\hline Herbal Medicine & 1 & 0.9 \\
\hline Glibenclamide & 13 & 12.3 \\
\hline Glimepirin & 6 & 5.7 \\
\hline Glukopak & 1 & 0.9 \\
\hline Metformin & 23 & 21.7 \\
\hline Glibenclamid \& Metformin & 39 & 36.8 \\
\hline Metformin \& acarbose & 1 & 0.9 \\
\hline Metformin \& Glimepirin & 17 & 16 \\
\hline
\end{tabular}

Table 2. Frequency Distribution of Motivation, ealth locus of control, and diet adherence in people with diabetes mellitus

\begin{tabular}{lcccc}
\hline \multicolumn{1}{c}{ Variable } & $\begin{array}{c}\text { Sub } \\
\text { Variable }\end{array}$ & Category & f & \% \\
\hline Motivation & Intrinsic & Less & 41 & 38.7 \\
& & Good & 65 & 61.3 \\
& Total & 106 & 100 \\
& Extrinsic & Less & 99 & 934 \\
& & Good & 7 & 6.6 \\
& Total & 106 & 100 \\
Health locus & Internal & Low & 56 & 52.8 \\
of control & & High & 50 & 47.2 \\
& Total & 106 & 100 \\
& Powerful & Low & 45 & 42.5 \\
& others & High & 61 & 57.5 \\
& Total & 106 & 100 \\
& Chance & Low & 43 & 40.6 \\
& & High & 63 & 59.4 \\
& Total & 106 & 100 \\
Diet adherence in people & Poor & 7 & 6.6 \\
with diabetes mellitus & Fair & 29 & 27.4 \\
& & Good & 70 & 66 \\
& & Total & 106 & 100 \\
\hline
\end{tabular}


Table 3. Relationship of Motivation with DM Diet Adherence

\begin{tabular}{|c|c|c|c|c|c|c|c|c|c|c|}
\hline \multirow[t]{3}{*}{ Variable } & \multirow[t]{3}{*}{ Sub Variable } & \multirow[t]{3}{*}{ Category } & \multicolumn{6}{|c|}{$\begin{array}{l}\text { Diet adherence in people with diabetes } \\
\text { mellitus }\end{array}$} & \multicolumn{2}{|c|}{ Total } \\
\hline & & & \multicolumn{2}{|c|}{ Poor } & \multicolumn{2}{|c|}{ Fair } & \multicolumn{2}{|c|}{ Good } & \multirow[b]{2}{*}{$\Sigma$} & \multirow[b]{2}{*}{$\%$} \\
\hline & & & f & $\%$ & $\mathbf{f}$ & $\%$ & $\mathbf{f}$ & $\%$ & & \\
\hline \multirow[t]{5}{*}{ Motivation } & Intrinsic & Less & 6 & 5.7 & 9 & 8.5 & 26 & 24.5 & 41 & 38.7 \\
\hline & & Good & 1 & 0.9 & 20 & 18.9 & 44 & 41.5 & 65 & 61.3 \\
\hline & Extrinsic & Less & 7 & 6.6 & 28 & 26.4 & 64 & 60.4 & 99 & 93.4 \\
\hline & & Good & 0 & 0 & 1 & 0.9 & 6 & 5.7 & 7 & 6.6 \\
\hline & \multicolumn{10}{|c|}{ Spearman $\mathrm{p}=0.178$} \\
\hline
\end{tabular}

Table 4. Relationship of Health Locus of Control with DM Diet Adherence

\begin{tabular}{|c|c|c|c|c|c|c|c|c|c|c|}
\hline \multirow{3}{*}{ Variable } & \multirow{3}{*}{ Sub Variable } & \multirow[t]{3}{*}{ Category } & \multicolumn{6}{|c|}{ Diet adherence in people with diabetes mellitus } & \multicolumn{2}{|c|}{ Total } \\
\hline & & & \multicolumn{2}{|c|}{ Poor } & \multicolumn{2}{|c|}{ Fair } & \multicolumn{2}{|c|}{ Good } & \multirow[b]{2}{*}{$\Sigma$} & \multirow[b]{2}{*}{$\%$} \\
\hline & & & $\mathbf{f}$ & $\%$ & $\mathbf{F}$ & $\%$ & $\mathbf{F}$ & $\%$ & & \\
\hline \multirow{6}{*}{$\begin{array}{c}\text { Health locus } \\
\text { of control }\end{array}$} & Internal & Low & 7 & 6.6 & 17 & 16 & 32 & 30.2 & 56 & 52.8 \\
\hline & & High & 0 & 0 & 12 & 11.3 & 38 & 35.8 & 50 & 47.2 \\
\hline & Powerfull & Low & 6 & 5.7 & 14 & 13.2 & 25 & 23.6 & 45 & 42.5 \\
\hline & & High & 1 & 0.9 & 15 & 14.2 & 45 & 42.5 & 61 & 57.5 \\
\hline & Chance & Low & 5 & 4.7 & 16 & 15.1 & 22 & 20.8 & 43 & 40.6 \\
\hline & & High & 2 & 1.9 & 13 & 12.3 & 48 & 45.3 & 63 & 59.4 \\
\hline \multicolumn{11}{|c|}{ Spearman $\mathrm{p}=0.002$} \\
\hline
\end{tabular}

Health locus of control shows that there are 56 (52.8\%) having high internal health locus of control, namely patients who have control of their own health. $56(52.8 \%)$ in the low category, namely the respondents who have confidence in their health control with outside influences are more dominant. In the powerful others health locus of control, there are $61(57.5 \%)$ high patients who have confidence in health control all entrusted to others (health workers and family). In the powerful others health locus of control, there are 45 (42.5\%) low, namely patients who have health control beliefs in addition to other factors that affect their health. There is 63 (59.4\%) high health locus of control chance, that is, the patient believes more in fate, luck, luck, or opportunity that has a big influence on his health. 43 respondents $(40.6 \%)$ were low, namely patients who had confidence in health control other than the factors of fate, luck or opportunities that affected their health. From the research data it can be explained that health locus control in patients with diabetes in Surabaya has control over their health, the most dominant of which is health locus control chance, namely the patient has the confidence that the patient's control is in the factors of fate, luck or opportunities that affect his health. Health locus of control is a continuum, sometimes a person can be "internal" and "external" at the same time (Azlin, 2007).

Diet adherence in people with diabetes mellitus shows the distribution of the most respondents was good diet adherence in diabetes mellitus, namely 70 (66\%) respondents. $29(27.4 \%)$ had adequate dietary adherence, and 7 (6.6\%) had poor dietary adherence. From the research data it can be explained that the most dominant are respondents who have good dietary adherence because patients think they still have the opportunity to improve their health, but when patients are out of control of their trust in destiny and tempted to the surrounding environment, patients can break the diet which must be done.

Table 3 shows that respondents who have poor intrinsic motivation, the majority have good DM diet adherence, namely 26 (24.5\%) respondents, but also there are $6(5.7 \%)$ respondents who have poor diet adherence. While respondents who have good intrinsic motivation there are 44 (41.5\%) respondents who have a good DM diet adherence and only $1(0.9 \%)$ respondents with good intrinsic motivation who have poor diet adherence. Respondents who had extrinsic motivation were not good, the majority had good DM diet adherence, 64 $(60.4 \%)$ respondents, and there were 7 (6.6\%) respondents who had poor diet adherence. While respondents who had the good extrinsic motivation, there were $6(5.7 \%)$ respondents who had a good diet adherence, and none of the respondents had a poor diet adherence that was equal to $0(0 \%)$ respondents. The analysis results show that the proportion coefficient ( $\mathrm{p}$ ) is 0.178 . Thus $\mathrm{p}=0.178$ is greater than the level of $0=0.05$. This means that the hypothesis (H1) is rejected, that there is no relationship between motivation and DM diet adherence.

Table 4 shows that respondents who had a low internal health locus of control, the majority had a good DM diet adherence, namely $32(30.2 \%)$ but also there were $7(6.6 \%)$ respondents who had poor diet adherence. Whereas respondents who had a high internal health locus of control, the majority were 38 (35.8\%) respondents who had a good diet adherence, and there were no respondents with high internal health locus of control who had poor diet 
adherence. Respondents who had low others health locus of control, the majority had good DM diet adherence, namely 25 (23.6\%) but also there were 6 (5.7\%) respondents who had poor diet adherence. Respondents who have powerful others Health locus of control are high, the majority of which are 45 $(42.5 \%)$ respondents have good diet adherence, and respondents with high powerful others health locus of control who have poor diet adherence only 1 (0.9 $\%)$. Respondents who had a low chance of health locus of control, the majority had good adherence to the diabetes mellitus diet which was 22 (20.8\%) and there were $5(4.7 \%)$ respondents who had poor diet adherence. While respondents who had a high chance of health locus of control, the majority of them were 48 (45.3\%) respondents who had a good diet adherence, and respondents with a high chance of health locus of control who had poor diet adherence were only $2(1.9 \%)$ The analysis results show that the proportion coefficient (p) is 0.002 . Thus $\mathrm{p}=0.002$ is smaller than the level of $=0.05$. This means that the hypothesis (H1) is accepted, that there is a relationship between health locus of control and DM diet adherence.

\section{DISCUSSION}

The results of a study in the relationship between DM diet motivation and adherence obtained $p>\alpha$, which means that $\mathrm{H} 1$ was rejected in other words there was no relationship between motivation and adherence to DM patients' diets. Basically, motivation is the interaction of a person with a particular situation he faces. Notoatmodjo (2010) states that motivation is an impulse from within a person that causes the person to carry out certain activities to achieve a goal. In a person, there is a need or desire for an object outside the person. Motivation has a very large role in the formation of DM patient behavior including adherence in carrying out a diet. Motivation is a predictor of adherence in regimens and glycemic control (Butler, 2002). Some research shows that someone who has high motivation will show positive results in DM management such as increasing participation in physical exercise programs and reporting symptoms of low depression (Wu, 2007).

Based on the results of the research obtained, researchers argue that the lack of meaningful motivation for adherence to DM diets, many factors influence motivation in adherence with DM diets. Respondents who have good motivation do not guarantee that the respondent has a good DM diet. The fact that in the community that most respondents said that their biggest motivation to recover and comply with the DM diet was their family, but respondents still violated DM diet rules because they felt bored and tempted by the food served.

The results of this study are in line with the research conducted by Pujiastuti, 2016 at the internal medicine polyclinic of Dr. RSUD Soehadi
Prijonegoro Sragen also got results that there was no relationship between motivation and adherence to the DM diet program. According to the results of interviews with respondents, some respondents said that the respondent's family still provided food that should not be allowed or had to be reduced by DM sufferers, especially during the month of Ramadan. Respondents' families still provide sweet and highcalorie foods, such as compote and fried foods. This family has indeed reminded the respondents not to eat these foods, but the respondents continued to eat foods that DM patients should not eat. It affects the motivation of respondents in adherence with DM diets.

This research is different from the results of research conducted by Muflihatin, S. K \& Komala (2016) and research conducted Risti and Isnaeni (2017) which states that there is a significant relationship between self-motivation and DM diet adherence. Behavioral attitudes in individual health are influenced by an individual's self-motivation to behave in a healthy manner. Without motivation in the diet setting, DM patients will experience nonadherence in regulating their daily diet. Respondents of good motivation have the opportunity to adhere to the DM diet for 329,667 times compared to respondents less motivation. Individuals will be motivated to take action if the action has a purpose, is planned. Motivation that exists within an individual is formed within a person and is influenced by two main factors, namely stimulus which is a factor that comes from outside a person (external factors) such as physical environmental factors such as social, cultural, habits, economic factors and responses from within self (internal factors) such as attention, observation, perception, motivation, fantasy, suggestion, depression and so on that respond to external stimuli. Thus, factors that are embedded in themselves can affect selfresilience in maintaining motivation to achieve a goal.

The results of study on the relationship of health locus of control and DM dietary adherence obtained $\mathrm{p}<\alpha$, which means that $\mathrm{H} 1$ was accepted in other words the relationship between health locus of control and dietary adherence of DM patients. The results of this analysis are supported by the results of research conducted by Safitri (2013) namely there is a significant relationship between health locus of control and adherence to DM diet management. Research conducted Adnyani et al., (2015) There is a significant relationship between health locus of control and adherence to DM diet management. The behavior of a DM diet is determined by several internal factors such as a strong desire to recover within oneself, as well as external factors such as family support factors or support from health workers or from the environment, culture and information and knowledge possessed by someone related to health is considered as a capital for someone to behave healthily. 
The results of this study indicate that individuals who have the highest chance of locus of control have the highest health locus of control, others and internal. Health locus of control chance is the patient is more confident in fate, fate, luck, or opportunity that has a big influence on his health. So this makes the respondents not feel depressed about the recommended diet and make respondents better in following dietary recommendations.

The other high powerful health locus of control is the second most HLOC. This is evidenced by the fact that some respondents in the study said that they always depend on health workers but are reluctant to take actions aimed at improving their health. This tendency occurs because the culture of the Indonesian people are always dependent on each other and the experience and dependence of patients on health workers.

High internal health locus of control is the third most HLOC. This is evidenced by the fact that there are still research respondents who state that respondents are lazy and bored to follow the DM diet. This shows that the patient's control of himself is still lacking. This shows that respondents do not believe in themselves and there is no willingness of themselves to improve their health status. Respondents were not aware that internal control had a big role in improving their health status.

Health locus of control is a continuum, sometimes a person can be "internal" and "external" at the same time (Azlin, 2007). Health locus of control (HLOC) is something that is in someone personality that has an influence on health and is one of the factors that influence DM diet adherence. Health locus of control also plays an important role in determining public health behavior (Bonichini, Axia and Bornstein, 2009). The link between health locus of control and adherence is that individuals will not carry out health behaviors unless they have a strong desire to be healthy and at least have knowledge about health.

In this study, researchers have argued about the link between health locus of control and adherence. The results showed that health locus of control had more obedience. This is inversely proportional to the research conducted by Adnyani, I. A. P., Widyanthari, D. M. \& Saputra (2011) that individuals with internal HLOC are more adherent to the DM diet than individuals with external HLOC. The average respondent said that there were no problems in eating arrangements and the patient did not feel tortured concerning the type and amount of food recommended, but at certain times the patient felt unable to follow dietary rules when there was a big event or family event. This shows that the patient's control of himself is still lacking and if this continues to be maintained, then the non-adherence of patients in undergoing a DM diet tends to decrease.

\section{CONCLUSION}

Motivation with DM diet adherence has no relationship with each other. This is evidenced by the presence of other factors that influence individual motivation in dietary adherence. Health locus of control with DM diet adherence has a relationship with each other. This is evidenced by DM patients who have good health locus of control who do not feel pressured towards the recommended diet and make respondents better in following dietary recommendations.

This study does not control the factors that influence perceptions of respondents' behavioral control, such as educational factors, age factors, cultural factors and environmental factors that can influence the filling of motivation questionnaires, health locus of control and DM dietary compliance. Need for further research regarding the factors that influence motivation, health locus of control and DM dietary compliance.

\section{REFERENCES}

Adnyani, I. A. P. S., Widyanthari, D. M. and Kadek Saputra (2015). Hubungan Health Locus of Control dengan Kepatuhan Penatalaksanaan Diet DM Tipe 2 di Paguyuban DM Puskesmas III Denpasar Utara. Journal, Ners, 3(2), pp. 7-14.

Azlin (2007) 'Health Locus of Control Among Noncompliance 7'.

Bonichini, S., Axia, G. and Bornstein, M. H. (2009). Validation of the parent health locus of control scales in an Italian sample. Italian Journal of Pediatrics, 35(13), pp. 1-5. doi: 10.1186/18247288-35-13.

Butler, H. A. (2002). Motivation: The role in diabetes self-management in older adults. Available at: http://proquest.umi.com/pqdweb.

Dinkes Jatim (2016). Laporan Tahunan Dinas Kesehatan 2016. Jawa Timur: Dinas Kesehatan.

Indarwati, D., Riskiana, Rusmariana, A., \& Hartanti, R. D. (2012). Hubungan Motivasi Dengan Kepatuhan Diet Diabetes Melitus Pada Pasien Diabetes'. Available at: https://caridokumen.com/queue/motivasidengan-kepatuhan-diet-dm_5a44a23fb7d7bc7b7a75f4d8_pdf?queue_id=-1.

Indriyati, D. S. \& Widyarini, N. (2012). Pengaruh Health Locus of Control terhadap kepatuhan Diet pada Penderita Hipertensi', pp. 1-8.

International Diabetes Federation (2017). IDF Diabetes Atlas Eighth Edition 2017, International Diabetes Federation. doi: 10.1016/j.diabres.2009.10.007.

Kementrian Kesehatan RI (2014). Infodatin (Pusat data dan Informasi kementrian Kesehatan RI)'. Jakarta: Kemenkes RI.

Kominfo (2015). Masih Tinggi, Prevalensi Diabetes di Jatim, 30 Sep 2015. Available at: http://kominfo.jatimprov.go.id/read/umum/mas ih-tinggi-prevalensi-diabetes-di-jatim-.

Muflihatin, S. K \& Komala, I. (2016). Hubungan Motivasi dengan Kepatuhan Diet Diabetes pada Pasien Diabetes Mellitus Tipe II di Puskesmas Sempaja Samarinda. Jurnal Ilmu Kesehatan, 4. 
Available http://ojs.stikesmuda.ac.id/index.php/ilmukesehatan/article/view/35/17.

Notoatmodjo (2010). Ilmu Perilaku Kesehatan. Jakarta: Rineka Cipta.

Perkeni (2015). Konsensus Pengelolaan dan Pencegahan Diabetes Melitus Tipe 2 di Indonesia 2015. PB. Perkeni.

Pujiastuti, E. (2016). Hubungan pengetahuan dan motivasi dengan kepatuhan diet pada pasien diabetes mellitus tipe ii di poliklinik penyakit dalam rsud dr. soehadi prijonegoro sragen. Stikes Kusuma Husada Surakarta.

Risti, K., and Isnaeni, F. (2017). Hubungan Motivasi Diri dan Pengetahuan Gizi terhadap Kepatuhan Diet DM pada Pasien Diabetes Mellitus Tipe II Rawat Jalan di RSUD Karanganyar', Jurnal Kesehatan, 10(2), pp. 94-103.

Safitri, I. N. (2013). Kepatuhan Penderita Diabetes Mellitus Tipe II Ditinjau dari Locus of Control', Jipt, 1(2), pp. 273-290.

at:
Saifunurmazah, D. (2013). Kepatuhan Penderita Diabetes Mellitus. Universitas Negeri Semarang. Available

at: lib.unnes.ac.id/17487/1/1550408022.pdf.

Tera, B. H. A. (2011). Determinan Ketidakpatuhan Diet Penderita Diabetes Melitus Tipe 2', 2. Available at: http://eprints.undip.ac.id/32591/1/393_Banu_H anifah_Al_Tera_G2C007014.pdf.

World Health Organization (2003). Adherence to Long-Term Therapies: Evidence For Action Adherence to Long-Term Therapies. Switzerland: WHO.

Wu, S. F. (2007). Effectiveness of self-management for person with type 2 diabetes following the implementation of a self-efficacy enhancing intervention program in Taiwan. Queensland University of Technology. Available at: http://eprints.qut.edu.au/16385/1/ShuFang_Wu_Thesis.pdf. 